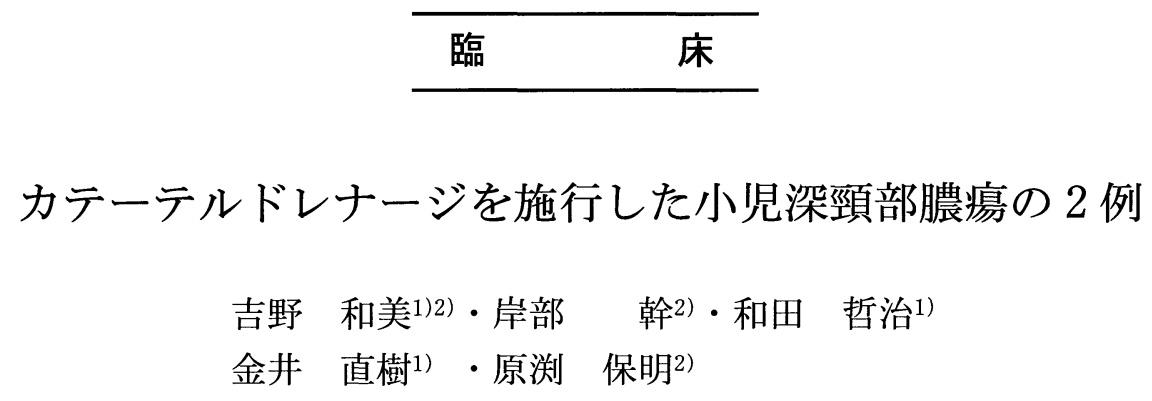

\title{
Catheter Drainage of Neck Abscess in Children
}

\author{
Kazumi Yoshino \\ (Kitami Red Cross Hospital, Asahikawa Medical College) \\ Kan Kishibe and Yasuaki Harabuchi \\ (Asahikawa Medical College) \\ Tetsuji Wada and Naoki Kanai \\ (Kitami Red Cross Hospital)
}

\begin{abstract}
Image-guided percutaneous drainage has been shown to be a safe and effective alternative to surgery in the management of neck abscess. Two patients, 7-year and 4-month-old girls, were treated with X-ray fluoroscopy and ultrasonography-guided percutaneous $7 \mathrm{Fr}$ trocar-type pigtail catheter drainage and antimicrobial therapy. This method was performed without complications and open surgical drainage was avoided in both cases. One patient had a persistent abscess, but was treated successfully by repeated catheter drainages.

Percutaneous drainage may be a useful alternative to surgical drainage in a selected group of patients with localized, smaller abscess without imminent airway obstruction.
\end{abstract}

Key words : neck abscess, pigtail catheter, percutaneous drainage, ECHO-guided

はじめに

深頸部膿瘍の治療は，抗生剂投与とドレナージが基 本であり, 対応を誤ると縱隔炎, 敗血症, 気道閉塞, 頸 動脈破裂などの合併症から不幸な転帰をとることもあ る1) 3). 外切開を用いたドレナージの場合，術後の醜形 や入院期間の長期化が問題になる場合がある．近年内科 領域では肝膿瘍や腎膿瘍に対して CT やエコーガイド下 でカテーテル治療が用いられており，良好な結果が得ら れている4). 今回，われわれは小児深頸部膿瘍に対して， カテーテルを用いて治療し, 良好な結果が得られたので
報告する。

症例 $1: 7$ 歳, 女览.

$$
\text { 症例 }
$$

主訴：左頸部腫脹。

現病歴: 平成 16 年 2 月 24 日より左頸部の疼痛, 腫脹, 発熱が認められた. 3 月 5 日当院小児科を受診, 同日当 科紹介された。軽度の開口障害は認めたが，呼吸困難は なかった。

既往歷：特記すべき事項なし. 


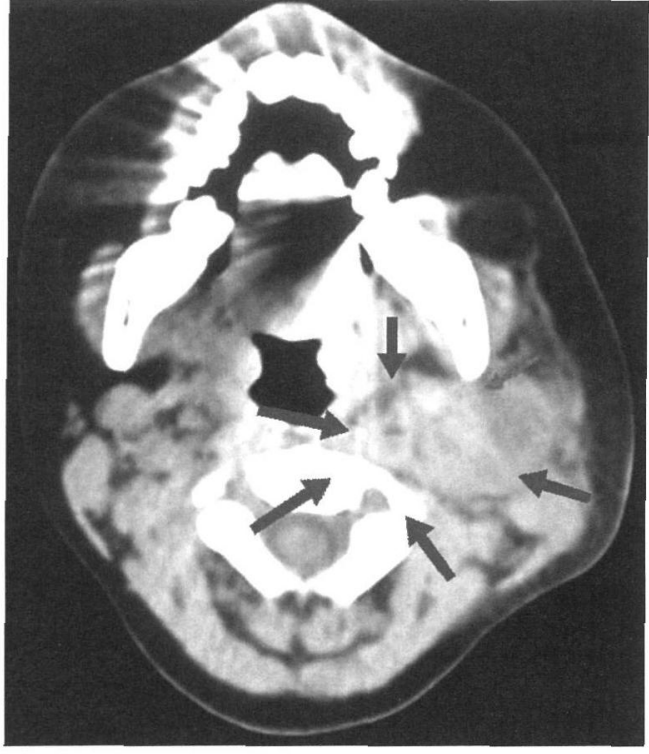

図 1 症例 1 の初䛦時頸部 CT（3月 5 日）

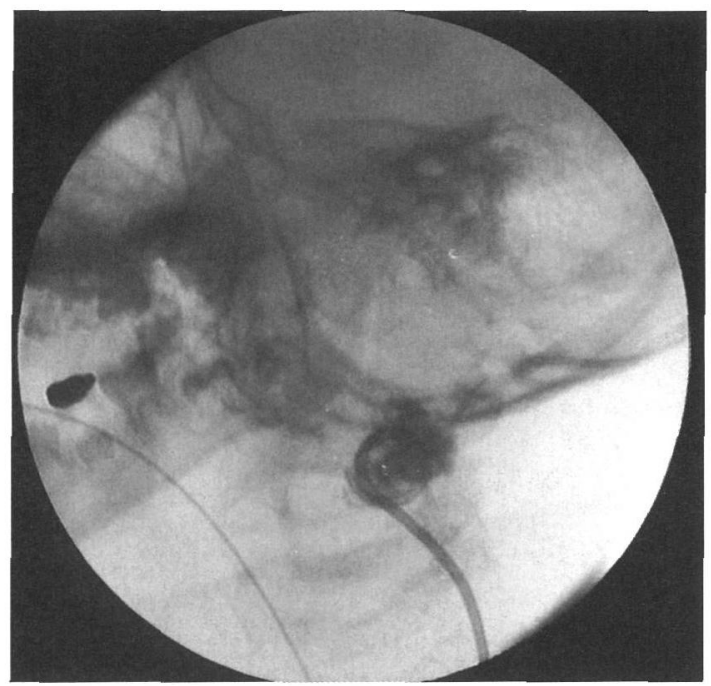

図 2 症例 1 の透視画像

理学所見：左澦下部に圧痛を伴った腫脹, 左咽頭壁の 腫脹を認めた。喉頭は異常を認めなかった。

検查所見：白血球数 $14210 / \mu \mathrm{l}, \mathrm{CRP} 9.72 \mathrm{mg} / \mathrm{dl}$ と強い 炎症反応を認めた。

画像所見：造影 CT（図 1）では, 左副咽頭間隙に $3 \times$ $3 \times 2 \mathrm{~cm}$ の膿瘍形成が認められた。

経過：即日，全身麻酔下にカテーテル治療を施行した (図 2，3）。X 線透視下，エコーガイド下にセルディン

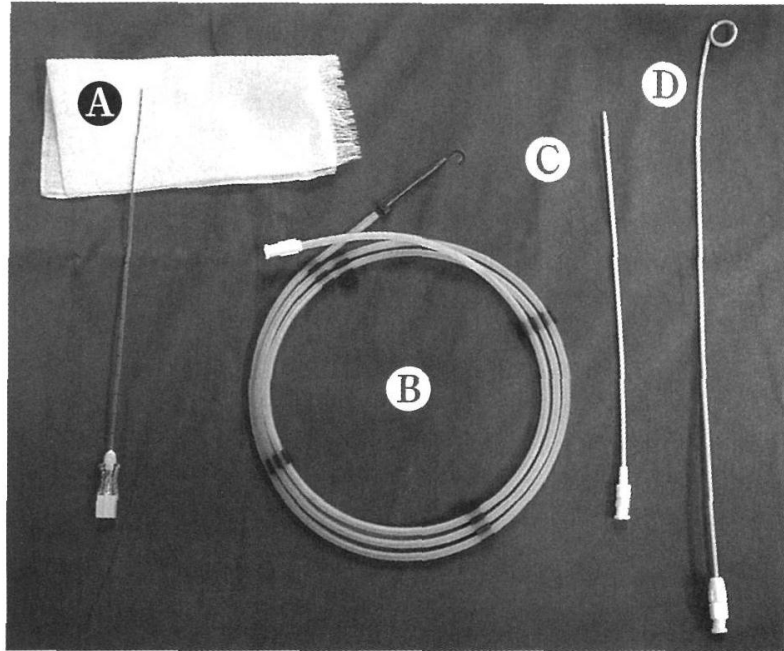

図 3 使用器具

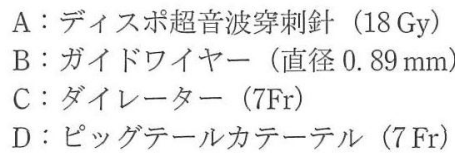

ガー法を用いて行った。エコーで血管の走行，膿瘍の位 置を確認後，穿刺部に小切開を加え外套付の穿刺針を刺 入した，膿瘍内に針の先端が到達したのを確認し，少量 の膿を培養検查用に採取した。次に，ガイドワイヤーを 入れ， $\mathrm{X}$ 線透視下に造影剂を注入し膿瘍腔内であること を確認のうえ，ループを作成した，ダイレーターで穿刺 部位のルートを広げた後, 7-Frのピッグテールカテーテ ルを挿入した。膿瘍腔を生理食塩水で洗浄した後, $\mathrm{X}$ 線 透視下に先端位置を再度確認し，頸部皮膚に絹糸で固定 した. カテーテルには SB バック（秋田住友ベーク株式 会社）のリザーバーに接続し，院圧をかけた。留置後は 1 日 1 回洗浄を行った. 洗浄は三方活栓から生食 5-10 ml を用いて洗浄液がきれいになるまで行った。術前には顔 面神経や血管の損傷の可能性，外切開に变更する可能性 を説明し，インフォームド・コンセントを得た。術後ス ルバクタム/セファペラゾン $1 \mathrm{~g} /$ 回，2回／日を 13 日 間点滴静注した。術後 4 日目より解熱し，膿もほとんど 出なくなったため, 術後 6 日目にドレーンを拢去した。 術後 4 日目の頸部 CT で膿瘍残存は認めず，経過順調で 2 週間で退院となった (図 4). 細菌検查では, streptococcus pyogenes が検出された. 経過中, 顔面神経麻痺や出血など の合併症は認めなかった。

症例 $2: 4$ 力, 女览。 


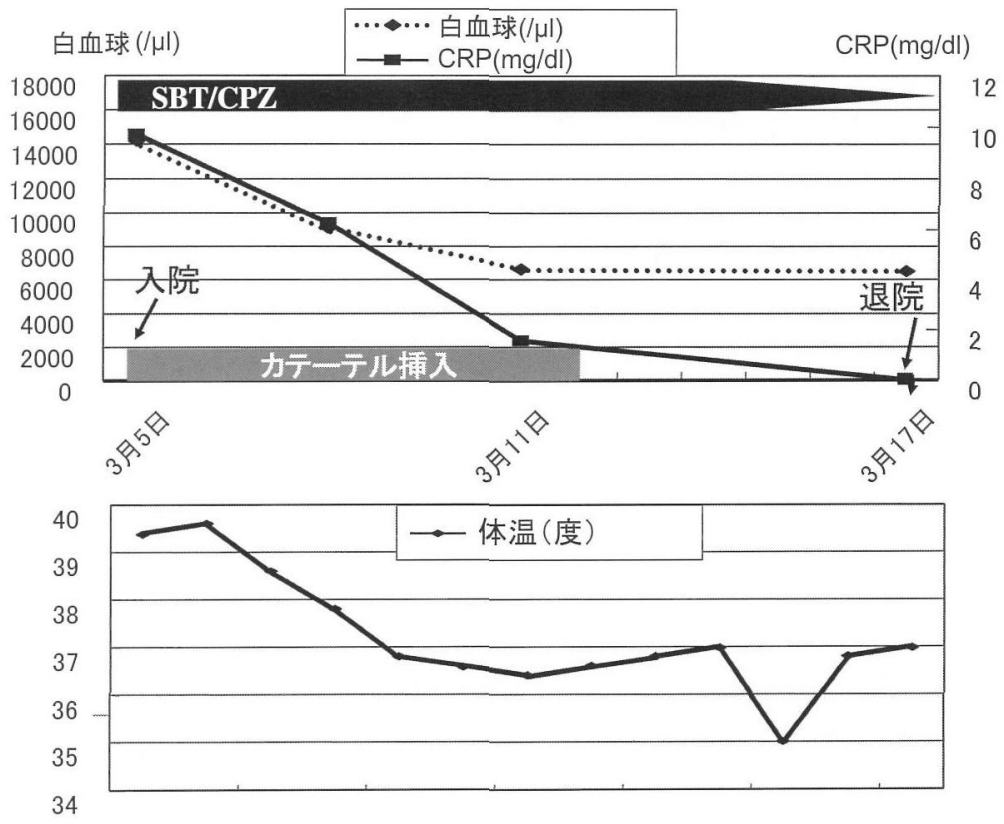

図 4 症例 1 の経過

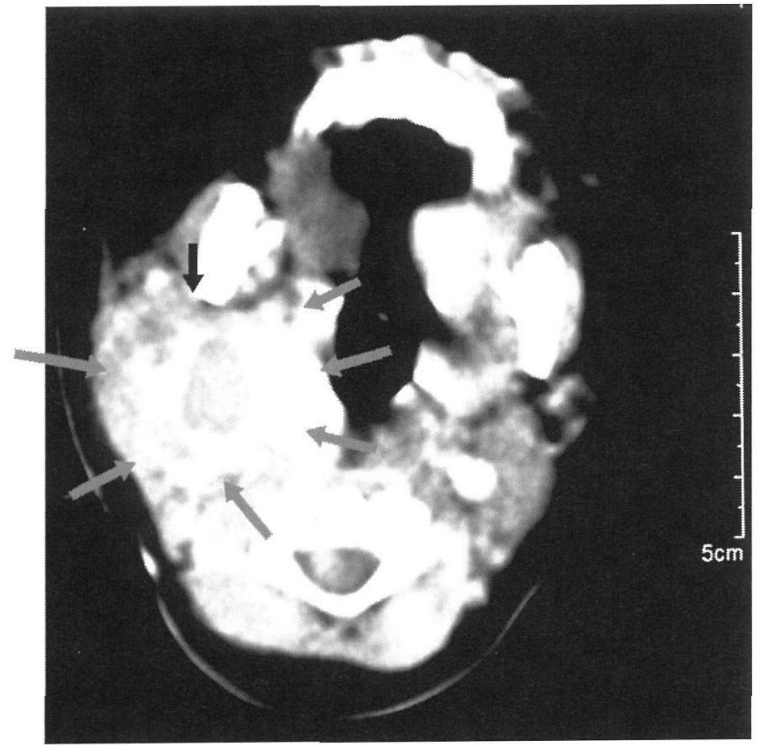

図 5 症例 2 の初䛦時頸部 CT (9月 9 日)

主訴：右頸部腫脹.

現病歴: 平成 15 年 9 月 3 日より 38.0 度の発熱, 右頸 部腫脹を認め, 近医で抗生剤投与されるも改善せず，9 月 9 日当院小児科紹介され, 翌日当科紹介となる. 開口 障害や呼吸困難は認めなかった。

渑往歴：特記すべき事項なし。

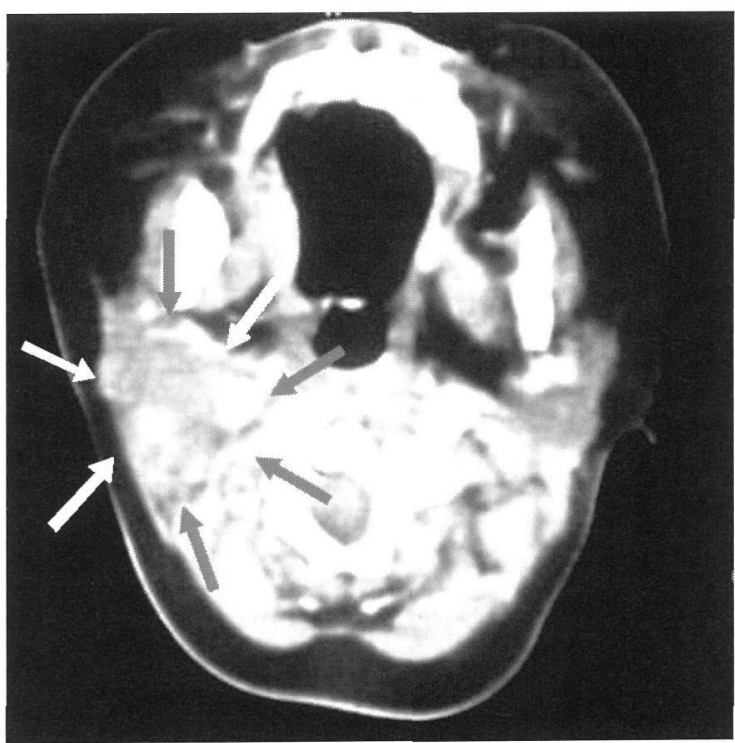

図 6 症例 2 の術後頸部 CT (9月 25 日)

理学所見：右顎下部に圧痛を伴った腫脹，右咽頭の腫 脤を認めた。喉頭所見は正常であった。

検查所見：白血球数 $25760 / \mu 1, C R P 3.37 \mathrm{mg} / \mathrm{dl}$ と炎症 反応の上昇を認めた。

画像所見: 造影 CT で右副咽頭閒隙に約 $3.3 \mathrm{~cm}$ の腫溜 を認め, 内部濃瘍形成を認好を（図 5). 


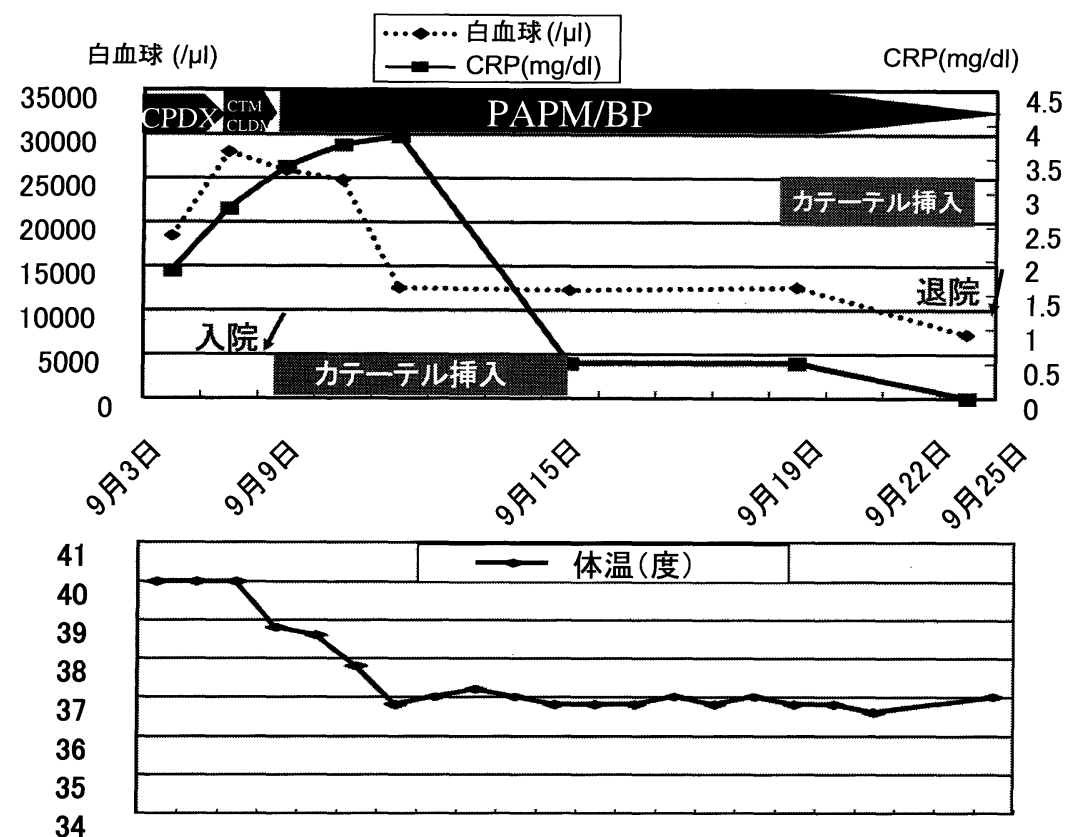

図 7 症例 2 の経過

治療 : 即日, 全身麻酔下にカテーテル治療を施行した。 術後は順調にCRP の低下を認めたが, 白血球数は 12000/ $\mu \mathrm{l}$ 台と正常化せず，右頸部の発赤腫脹が持続した. 術後 9 日目での CT で, $2.2 \times 1.4 \mathrm{~cm}$ の膿瘍の残存が認められ たため, 翌日に 2 回目のカテーテル治療を施行した. 抗 生剤は入院時セフォチアム $200 \mathrm{mg} /$ 回，3 回／日を 3 日 間とクリンダマイシン $30 \mathrm{mg} /$ 回，2 回／日を 2 日間の 点滴を施行していたが, 1 回目のドレナージ時の細菌検 查ではStaphylococcus aureus が検出され, 感受性を考慮し てパニペネム/ベタミプロン $120 \mathrm{mg} /$ 回，3 回／日を 12 日間へと変更した. その後の経過は順調で, 白血球数は 下がり, 炎症反応も消失したため, 9 月 22 日にカテーテ ルを抜去し，9 月 25 日の CT で膿瘍腔消失を確認し退院 となった（図 7). 経過中, 顔面神経麻痺や出血などの合 併症は認めなかった。

\section{考察}

一般に膿瘍治療の原則は排膿であり，従来は排膿操作 の主体は切開であった。耳鼻咽喉科領域では，扁桃周囲 膿瘍において穿刺と抗菌療法の組み合わせが切開に遜色 ない効果を示したことから，深頸部膿瘍一般に応用され 始めている5) 7). 特に近年では超音波ガイド下の穿刺を 用いることでその確実性が増している1).
Yeow $5^{8)}$ は単房性で気道閉塞をきたしていない症例に 対して, 超音波ガイド下にカテーテル法を施行している. 15 例中 13 例 $(87 \%)$ で，外科的切開を施行しなくて済 んだとしている．繰り返し施行することも可能であり， 特別な合併症もきたさなかったとしている. Herzon ${ }^{5)}$ は, 頸部膿瘍の患者 25 人に対して穿刺, ドレナージを施行 し，80\%の割合で成功したとしている. Serour ら ${ }^{9)}$ は, 化膿性リンパ節炎に対して穿刺を行い，良好な成績を得 ている．また，特別な合併症もきたさなかったとしてい る。

深頸部感染症が疑われた場合，一般的には気道閉塞症 状，CT 画像による膿瘍の拡がり，糖尿病などの合併症 の有無を総合的に判断して治療方針を決定する必要があ る110) 12). 当科の方針としては，気道症状があれば，気 道確保を優先し，その後造影 CT により，膿瘍形成の状 態を把握する，膿瘍形成がある場合は，限局していれば 穿刺，カテーテル治療を選択する．膿瘍形成が広範囲の 場合や非限局性で壊死性筋膜炎が疑われる場合には外科 的な切開排膿を選択する. 造影 CT にて膿瘍形成が認め られない，あるいは，微小なものはまず，保存的に抗生 剤投与などを行う。気道が確保されていない状態ではス テロイド剤は基本的には使用しない. いずれも, $24 \sim 72$ 時間みて改善が得られない場合は, 再評価のため造影 CT 


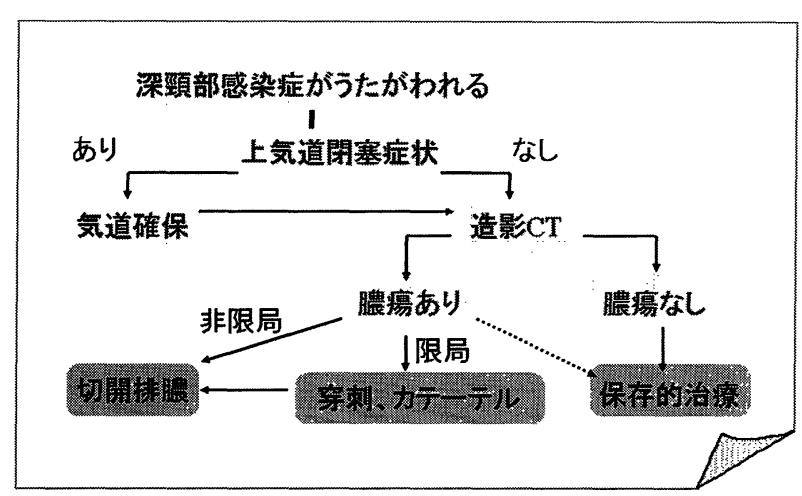

図 8 深頸部感染症に対する当科での方針

表 1 治療法による利点と欠点

\begin{tabular}{c|l|l}
\hline \hline & \multicolumn{1}{|c|}{ 利点 } & \multicolumn{1}{c}{ 欠点 } \\
\hline 外切開 & $\begin{array}{l}\text { ・解剖学的位置が判りや } \\
\text { すい } \\
\text { †排膿が簡便 }\end{array}$ & $\begin{array}{l}\text { 傷が大きくなる } \\
\text { 処置が煩雑 }\end{array}$ \\
\hline 穿 刺 & $\begin{array}{l}\text { ・傷が小さい } \\
\text { ・侵襲が少ない }\end{array}$ & $\begin{array}{l}\text { ・排膿が不十分になるこ } \\
\text { とがある } \\
\text { 大出血の可能性 }\end{array}$
\end{tabular}

を撮影する，その結果に基づきさらに保存的に経過をみ るか, 繰り返し穿刺を行うか, 積極的に外科的に切開排 膿へ切り替えるかを判断する（図 8).

外切開とカテーテル治療を比較した場合, 外切開では 直視下に解剖学的位置を確かめながら, 確実に大きく切 開排膿を行らことができる反面, 手術侵襲が大きくなる ことや，術創の閉鎖に時間がかかり入院期間が長期にな りやすいこと, 術後の瘢痕形成など美容整容上の問題が 生じることが挙げられる。一方カテーテル治療の場合, 傷が小さく美容上有利で，術創の閉鎖に時間がかからな いため, 入院期間の短縮ができる. 欠点としてはエコー 下に施行しても血管や神経の損傷の可能性はあり, 血腫 などの合併症が起きた場合や効果が不十分な場合はいつ でも外切開へ切り替えられる準備が必要となる。 また， 嫌気性感染の場合に閉鎖系で持続吸引するカテーテル法 では治療効果が弱い可能性が考えられるが，カテーテル 法から外切開へ変更した症例で嫌気性感染がはっきりと した原因と考察された報告はない，深頸部感染症は夜間 緊急手術が行われることが多く, 嫌気性菌の検查を正確 に行うことができない13) と報告している文献もあり，今 後の検討が必要と考えられた。

今回経験した 2 例は気道症状がなく, 膿瘍が比較的限
局しており，また女児のため保護者の希望む配慮してカ テーテル治療を施行した。 症例 2 では 2 回カテーテル治 療を施行したが, 特に合併症は認めなかった。

\section{まとめ}

今回小児の深頸部膿瘍に対し，カテーテル法により治 療した症例を報告した．消化器系で使用するピッグテー ルカテーテルを使用し，良好な結果が得られた。、いすれ も早期治療により，外切開を加えることなく膿瘍消失と 炎症反応の陰性化をはかれた。

本論文の要旨は第 67 回耳鼻咽喉科臨床学会 (平成 17 年 7 月, 松山）においてロ演した.

\section{参考文献}

1）市村恵一：深頸部感染症の臨床. 耳鼻臨床 $97: 573 \sim 582$, 2004.

2) 加我君孝, 伊藤壽一：5 深頸部感染症. 目で見る救急処置 マニュアル (耳鼻咽喉科領域編). $1 \sim 8$ 頁, 国際医学出版 株式会社，東京，2002。

3) 菊地 茂: 深頸部感染症を疑う. Medicina $40: 629 \sim 633$, 2003.

4）真弓勝志, 藤尾長久, 鷹取 浩, 他 : 当院における肝膿陽 症例の検討. 兵庫全外科医会誌 $38: 39 \sim 41,2003$.

5) Herzon FS : Needle aspiration of nonperitonsillar head and neck abscesses. A six-year experience. Arch Otolaryngol Head Neck Surg $114: 1312 \sim 1314,1988$.

6) de Marie S, Tjon A Tham RT, van der Mey AG, et al. : Clinical infections and nonsurgical treatment of parapharyngeal space infections complicating throat infection. Rev Infect Dis 11:975 $\sim 982,1989$.

7) Brodsky L, Belles W, Brody A, et al. : Needle aspiration of neck abscesses in children. Clin Pediatr 31:71 76, 1992.

8) Yeow KM, Liao CT and Hao SP : US-guided needle aspiration and catheter drainage as an alternative to open surgical drainage for uniloculated neck abscess. J Vasc Interv Radiol 12:589 $\sim 594,2001$.

9) Serour F, Gorenstein A and Somekh E : Needle aspiration for suppurative cervical lymphadenitis. Clin Pediatr $41: 471 \sim$ 474,2002

10）木下恵司，大日方薰 : 深頸部膿瘍の診断と治療. 小児内科 $36: 202 \sim 206,2004$.

11）石川敏夫, 戸島 均: 重症深頸部膿瘍の 2 例. 耳鼻臨床 95 : $855 \sim 861,2002$.

12）原田輝彦：深頸部膿瘍の超音波診断. MB ENT $14: 66$ ～ $74,2002$.

13）金谷毅夫，松田明史，鎌田啓太，他：当科における深頸部 膿瘍 73 例の集計. 口腔咽頭科 $15: 209 \sim 214,2003$.

原稿受付：平成19年 6 月 5 日

原稿採択：平成19年 9 月 13 日

別刷請求先 : 吉野和美

厂062-8618 札幌市豊平区中の島1条8-3-18

北海道社会保険病院耳鼻咽喉科 